\title{
UDC $81^{\prime} 42$
}

\author{
FRAMES AND IMAGES FACING UKRAINE: \\ COMPARING GERMANY'S AND RUSSIA'S MEDIA PERCEPTIONS \\ OF THE EU RELATIONS WITH UKRAINE \\ Katharina Kleinschnitger \\ (Technical University of Darmstadt, Germany) \\ Michèle Knodt \\ (Technical University of Darmstadt, Germany) \\ Nadiya Safonova \\ (Carleton University, Ottawa, Canada)
}

\begin{abstract}
Katharina Kleinschnitger, Michèle Knodt, and Nadiya Safonova. Frames and images facing Ukraine: comparing Germany's and Russia's media perceptions of the EU relations with Ukraine. The recent EU-Ukraine Summit in July 2018 demonstrated that the leaders of the EU and Ukraine have committed to further deepen the political association and economic integration of Ukraine with the EU. Yet, this "strong partnership," based on a joint association agreement, has been overshadowed by Russia's illegal annexation of Crimea and its instigation of the war in Donbas. Given that Ukraine is an important geopolitical neighbour for both the EU and Russia, the EU and its Member States - especially Germany and France - have taken on the role of mediators in the Russia-Ukraine conflict. The focus of our study is on the image of the EU-Ukraine relationship as a unique and outstanding case. Ukraine's close ties with Russia appear to be waning, however, the more Ukraine tries to strengthen its ties with the EU, the more Russia seems to resist. In this regard, we ask: How are the relationships between the EU and Ukraine are represented in German and Russian print media? How do the print media sources frame this relationship and what different images do they communicate? The content analysis of data draws diverging pictures: within the same period, the patterns of interaction between the EU and Ukraine, evolving within European Neighbourhood Policy and Eastern Partnership, tend to be depicted as far more cooperative in the German press, whereas Russia's print media portray EU-Ukraine relations as increasingly negative and more conflicted over the years.
\end{abstract}

Keywords: frames and images, media perceptions, content analysis, the EU, Ukraine, European Neighbourhood Policy, Eastern Partnership.

Катарина Кляйншнітгер, Мішель Кнодт, Надя Сафонова. Фрейми та образи, з якими стикається Україна: порівняння сприйняття відносин між ЄС та Україною, представленого в німецьких та російських засобах масової інформації. У світлі недавнього саміту ЄС-Україна, який відбувся в липні 2018 року, лідери СС і України зобов'язалися поглиблювати політичне об'єднання і економічну інтеграцію України з СС. Проте це "сильне партнерство", засноване на спільній угоді про співпрацю, затьмарене незаконною анексією Росією Криму та роздмухуванням нею війни на Донбасі. 3 огляду на те, що Україна геополітично є важливим сусідом як для $\mathrm{CC}$, так і для Росії, ЄС і його члени, особливо Німеччина і Франція, взяли на себе роль посередників в українсько-російському конфлікті. Основна увага в нашому дослідженні приділяється сприйняттю відносин між $\mathrm{CC}$ i Україною як унікального прикладу політичного співробітництва. У ситуації послаблення зв'язків між Україною та Росією зміцнення зв'язків України з СС викликає збільшення опору з боку Росії. У статті надаються відповіді на питання: Як відносини між СС і Україною сприймаються та подаються у друкованих ЗМІ Німеччини, і як ці відносини висвітлюються в Росії? Як засоби масової інформації зображують ці відносини, і як ці зображення відрізняються одне від іншого? Дослідження даних за 
допомогою контент-аналізу надає різні картини: протягом однакового періоду моделі взаємодії між ЄС і Україною, які набувають становлення в рамках Європейської політики сусідства та політики Східного партнерства, зображуються набагато більш дружніми в німецькій пресі, тоді як в друкованих ЗМІ Росії відносини СС і України виглядають більш негативними і неоднозначними.

Ключові слова: фрейми та образи, медійні сприйняття, контент-аналіз, ЄС, Україна, Європейська політика сусідства, Східне партнерство.

Катарина Кляйншнитгер, Мишель Кнодт, Надя Сафонова. Фреймы и образы, с которыми сталкивается Украина: сравнение восприятия отношений между ЕС и Украиной, представленного в немецких и российских средствах массовой информации. В свете недавнего саммита ЕС-Украина, состоявшегося в июле 2018 года, лидеры ЕС и Украины обязались углубить политическое объединение и экономическую интеграцию Украины с ЕС. Тем не менее, это "сильное партнерство", основанное на совместном соглашении о сотрудничестве, омрачено незаконной аннексией Россией Крыма и разжиганием ею войны на Донбассе. Учитывая то, что Украина геополитически является важным соседом как для ЕС, так и для России, ЕС и его члены, особенно Германия и Франция, взяли на себя роль посредников в украинско-российском конфликте. Основное внимание в нашем исследовании уделяется восприятию отношений между ЕС и Украиной как уникального примера политического сотрудничества. В ситуации ослабления связей Украины с Россией укрепление связей Украины с ЕС вызывает возрастание сопротивления со стороны России. В статье предлагаются ответы на такие вопросы: Как отношения между ЕС и Украиной воспринимаются и подаются в печатных СМИ Германии, и как те же отношения освещаются в России? Как средства массовой информации изображают эти отношения, и чем эти изображения отличаются друг от друга? Исследование данных с помощью контент-анализа дает разные картины: в течение одного и того же периода модели взаимодействия между ЕС и Украиной, формируемые в контексте Европейской политики соседства и политики Восточного партнерства, изображаются гораздо более дружескими в немецкой прессе, в то время как в печатных СМИ России отношения ЕС и Украины предстают более негативными и неоднозначными.

Ключевые слова: фреймы и образы, медийное восприятие, контент-анализ, ЕС, Украина, Европейская политика соседства, Восточное партнерство.

\section{Introduction}

On November 18, 2015, the High Representative for Foreign Affairs and Security Policy and the European Commission laid out the main ideas for the review of the European Neighbourhood Policy (ENP). Federica Mogherini stated, "We should switch from the idea that the European Union is at the centre, surrounded by neighbouring countries, to the idea of a new partnership based on cooperation" [EEAS 2015]. This phrase symbolised a turn in the ENP and highlighted that cooperation must be more "flexible" [European Commission 2015] in the future. Significantly, the Eastern Partnership (EaP) was heralded to be the "privileged relations" [Casier 2017: 17] within the neighbourhood. The 2016 EU Global Strategy (EUGS) echoed this sentiment and introduced the notion of principled pragmatism into the EU's foreign policy direction. The notion showed a new realism in the EU's foreign policy, especially in its neighbourhood policy, which focuses on security, hard power and interests. The new approach will most likely bring a change towards a stronger bilateralism between the EU and its member states on the one side, and ENP countries (Ukraine included) on the other side.

At the most recent EU-Ukraine Summit in July 2018, the leaders of the EU and Ukraine committed to further deepening of the political association and economic integration of Ukraine with the EU. Yet, this partnership based on a joint Association Agreement - which was signed in 2014 and finally entered into force on September 1, 2017 - has been overshadowed by Russia's illegal annexation of Crimea and its support of the Eastern Ukrainian separatists. With Ukraine remaining an important geopolitical and economic neighbour for both the EU and Russia, this article traces and analyses what frames and images of EU-Ukraine relations are communicated inside the EU vis-à-vis in Russia. Since there is a lack of representative pan-European news media ${ }^{1}$, 
this analysis focusses on German media. Germany is a key driver behind European integration and one of the most influential member states within the EU. Additionally, Germany has played a special role for the Eastern European states, historically, through its experiences as a divided state and the reunification in 1990. It is also involved in the EU-Ukraine relations in the context of the Russia-Ukraine conflict: it is one of the four mediators in the Minsk negotiation format.

Our analysis of the images of EU-Ukraine relations in Russia and Germany is guided by the following research questions: How is the relationship between the EU and Ukraine framed in Germany's and Russia's media discourses? What different frames and images do they communicate? Our inquiry is multidisciplinary. We synergise perspectives from political science, communications and media studies, and linguistics - a novel combination in the field of EU studies. Theoretically, this research case study is grounded within the framework of interpretative constructivism and the "cascading activation framing theory" by Robert Entman [2003; 2004]. We employ a mixed method undertaking qualitative and quantitative media content analysis. The study analyses images of EU-Ukraine relations in German and Russian print media. We selected two leading newspapers per country. In Germany, we chose Süddeutsche Zeitung and Frankfurter Allgemeine Zeitung as an EU-internal perspective on EU-Ukraine relations. The Russian sample as an EU-external perspective - included the influential Kommersant and Rossiskaya Gazeta. The comparison between the German and Russian leading newspapers draws a diverging picture: within the similar observation period, the interaction between the EU and Ukraine is framed to be far more cooperative in the German press, whereas Russia's print media portray EU-Ukraine relations as increasingly negative and conflicted over time.

The article proceeds in the following way. Firstly, it lays out the theoretical framework and then moves to explain the methodological approach, focusing on case selection and research method. Subsequently, it presents the empirical analysis including a discussion of the results. Finally, a conclusion summarizes our findings.

\section{Theoretical considerations and a methodological framework}

The following section outlines the underlying theoretical perspectives used to conceptualize our research case. In particular, our analysis of the perceived relationship between the EU and Ukraine engages with theoretical concepts of media representations/framing and the role of media in creating and shaping these. In this section, we discuss the methodology behind our empirical analysis, the specific choices in the research design and the method for our data collection.

The underlying epistemological approach of understanding the interactions of international actors, and specifically the EU and Ukraine, is informed by constructivism. Following the theoretical positions of interpretative constructivism, the images and framings of actors in media influence how these actors are perceived by the consumers of media products. This is, in particular, the case regarding foreign policy issues, as people mainly base their knowledge upon news media, due to the complex and distant character of foreign policy. In this analysis, an image is understood as "a reference to some aspect of the world, which contains within its own structure and in terms of its own structure a reference to the act of cognition, which generated it. It must say, not that the world is like this, but that it was recognized to have been like this by the image-maker, who leaves behind this record: not of the world, but of the act" [Cohen 1979, quoted in Bersick et al. 2012: 15]. Following this definition, framing of EU-Ukraine relations in German and Russian news is conceptualized in terms of a cognitive structure constructed with a help of an "image-maker" - in our case, newsmakers who map the image leaving a "record" in the form of media texts and visual support.

The main strand of media effects research postulates the agenda setting ability of media. Mass media are hypothesized to be "agenda setters" that select information for presentation, frame selected topics and thus possess an ability to influence the understanding of social issues and ultimately act as opinion formers for the recipient [see McCombs \& Shaw 1972]. In 1967, the 
sociologist Bernhard C. Cohen examined, by means of interviews, mechanisms that intervene between the newspaper industry and American foreign policy. His conclusion was that specifically in the field of foreign policy communications, newspapers "may not be successful much of the time in telling people what to think, but they are stunningly successful in telling its readers what to think about" [Cohen 1967: 13]. As a result, he identified the agenda-setting function as a "label" of a "short-term cognitive effect of the media" [Cohen 1967], i.e. the ability of news media to draw attention to certain issues and ignore other. Media are also argued to impact the ranking of topics in the public perceptions - through the volume of reports and the placement of the topic in the reportage. Media "image-makers" decide "which priority will be assigned to the problems at hand" [Vowe 2002: 18; own translation] and thus can potentially structure the public discussion.

A different conceptual take is proposed by Robert M. Entman [2003, 2004] in his theory of cascading activation framing. Entman developed his "cascading" model in 2003 on the basis of a large-scale study of numerous news media outlets in the US. The model hypothesizes how news about foreign policy spread and activate certain frames in a given society. The model consists of several tiers. The highest tier is the administration (government) who are argued to possess the utmost ability to spread and activate particular frames in foreign policy issue-areas. The following tiers are: other elites, media (who create news frames), and the general public (the least powerful tier is spreading and activating frames on foreign policy). Entman defines frames as "selecting and highlighting some facets of events or issues, and making connections among them so as to promote a particular interpretation, evaluation and/or solution" [Entman 2004: 5]. The cascading model suggests that the 'selected highlights' of information originating on the upper tier (the government) are then pushed down the cascade to the lowest tiers, the public, through the network of nonadministrative elites and news organizations that frame the messages about foreign policy [Entman 2003: 415]. The public can also use the media with its own interpretations and supply new frames through the media back up to the administration level [Entman 2003: 418-419] as a kind of "feedback loop". As such, the media level in the imaginary "cascade" has a central role in the flow of frames up and down the "stream". The media's role is significant in how the general public frames foreign policy and international relations, and perceives the changes in the world [see Chaban et al. 2014: 2]. In this sense, media frames play an important role in the generation of cognitive imagery and perceptions of international partners. It is important to note that according to Entman's model, frames of foreign policy that travel 'down' from the government to the public are more effective, than frames in the reverse flow - from the public to the government.

Our analysis, guided by Entman's definition of framing, is very much clear that framing is an extremely complex cognitive concept, understood differently in many works and used in numerous research designs in a differing way. Entman sees framing as the central process in which state officials and journalists - "image-makers" in the parley of this article - exert political influence on each other and the public [Entman 2003: 417]. According to Chaban et al. [2014: 4], this process reflects a struggle for the meaning that involves many different actors. Our analysis focuses the socalled "media frames" - frames generated by news media and designed to present the recipient with a preformed reality through communication symbols such as words and images" [see Chaban \& Holland 2008: 8].

In conclusion, this study assumes that political communication about external relations is not an arbitrary or unlimited flow of information, but rather consists of "packages of established mental maps and schemas" [Chaban et al. 2014: 2; see also Chaban \& Holland 2014, 2015; Elgström \& Chaban 2015]. We assume that the German and Russian news media create a set of particular nation-specific schemes when framing EU-Ukraine relations and these schematic frames may influence the perceptions of the readers (not lastly through stereotyping and priming mechanisms employed by the "image-makers"). These frames may be instrumental not only in shaping opinions but also in prompting national audiences' reactions to EU external action, and ultimately have an impact on the conduct of EU foreign policy. It is important to remember that media are capable to 
impact significantly what events become news and how they are proclaimed and presented [Chaban et al. 2008: 22]. Indeed, in the foreign policy communication, media often has a power to be the basic (and often single) source of information for the public [Chaban et al. 2014: 7]. Finally, media may also influence the external relations (of the EU and third countries) through its impact on policy- and decision-makers. They are also among the recipients of news media and may orientate their actions using the media frames and not on the reality itself [the so-called "CNN effect", see Livingstone 1997].

To answer our research questions - how are the relations between the EU and Ukraine framed in German and Russian media and what different frames and images do they communicate? - we employ mixed-method analysis, led by the qualitative approach first. Such an approach implies that the research process cannot be linear, but instead it is identified by circularity and interdependence between the different phases, which characterize a qualitative research project [Westle 2009: 116]. Quantitative elements of analysis follow. The observed sample is rather large and quantitative techniques for data collection and analysis are justified.

Content analysis with qualitative and quantitative elements is the leading research method in our study. It enables a systemic and consistent data analysis through the employment of the coding protocol applied to the both cases - coverage of EU-Ukraine relations in German and Russian media respectively. Furthermore, changes in the content over time can be examined [Häder 2006: 325]. The time period in the focus is from 2009 to 2015 . The year of 2009 is a meaningful starting point for the analysis. It marked the launch of the EU's EaP, the key instrument of the EU's foreign policy to further deepen the relationship with its Eastern neighbours both multilaterally and bilaterally with each of the six participating countries. The period of observation ends with an important EaP summit in 2015, which followed the Russia-Ukraine crisis. Our focus is German and Russian news coverage of EU-Ukraine relations during the specific periods around the biennial EaP summits in Prague (2009), Warsaw (2011), Vilnius (2013) and Riga (2015). We examine the EaP summits coverage one week before, and three days after each summit (Table 1). In total, approximately seven weeks of news media coverage was analysed. This seven-year period allows us to examine the trends, changes and variations in the imagery surrounding EU-Ukraine relations. Additionally, this time period is expected to profile a higher number of media items in which the EU is reported to interact with Ukraine.

Table 1

Periods of observation

\begin{tabular}{lll} 
EaP Summit & Duration & Period of observation \\
\hline Prague Summit & 7 May 2009 & 30 April - 10 May 2009 \\
\hline Warsaw Summit & $29-$ 30 September 2011 & 22 September - 3 October 2011 \\
\hline Vilnius Summit & $28-29$ November 2013 & 21 November - 2 December 2013 \\
\hline Riga Summit & $21-22$ May 2015 & 14-25 May 2015 \\
\hline
\end{tabular}

The framing of EU relations with Ukraine is traced from two different perspectives: from inside the EU (case-study Germany) and from outside the EU (case-study Russia). As mentioned above, Germany is a key driver behind European integration and one of the most influential EU member states [Semetko et al. 2000]. This status comes with the potential to influence public and political discourses within the EU and play a significant role in the relations with the Eastern European states, including Ukraine. It is not just about Germany's involvement in the Minsk peace processes (the Normandy contact group to mitigate the persistent war in the Donbass region of Eastern Ukraine since 2014). Germany also demonstrates a strong economic and political interest towards Ukraine. Russia also has a very strong economic and political interest in Ukraine due to their closely intertwined history, the size of the country, the geopolitical location (e.g. in terms of energy policy), and economic connections. Ukraine would be an important and suitable member for Russia's Eurasian Customs Union (EACU), however, Ukraine's Association Agreement (AA) with 
the EU hinders Ukraine's ability to join the EACU. Russia has tried to pressure Ukraine to drop its AA with the EU, and replace it with the EACU membership. This makes Ukraine a key player between the EU and Russia.

The focus of our study is on print media. In each case, we selected two influential, daily press outlets. In Germany, we chose Süddeutsche Zeitung (SZ) and Frankfurter Allgemeine Zeitung (FAZ). In Russia, the sample included the influetial Kommersant (Коммерсанть) and Rossiskaya Gazeta (Российская газета) (RG). All four newspapers are often used as credible references by policy- and decision-making elites in the respective countries. $S Z$ and $F A Z$ are the two daily, high quality newspapers with the highest circulation in Germany ${ }^{2}$. Politically, $S Z$ is seen as social liberal, leaning to the left, whereas $F A Z$ is a clearly centre leaning newspaper. Both reflect common attitudes and political viewpoints within the German media landscape. In the Russian sample the Kommersant is focussing economic issues and is, politically, considered to be a more liberal newspaper out of the two selected newspapers. $R G$ is the leading government newspaper that focuses more on domestic issues and reflects the ruling party's political base and its foreign policy stance.

The data were collected in German and Russian languages respectively. To collect the news items for our analysis, we used the following key words: "European Union" and "Ukraine". The search terms for the European Union also included such key words as "EU", "European Commission"/"EC", "European Central Bank"/"ECB", "European Court of Justice"/“ECJ", "European Parliament"/"EP", "EU Presidency", and finally "EU Council". The newspaper articles from the chosen Russian and German news outlets entered the sample if they mentioned Ukraine and at least one of the listed EU-related terms. In total, 160 news items were collected: the German dataset contains 111 articles and the Russian dataset consists of 49 news items in the observed period.

A crucial part of the media content analysis is the formulation of categories and sub-categories for the content analysis (Table 2). The categories are partly theory-based and partly empiricalbased. The theory-based formulation of categories derived from our research question, while the empirically-based categories are derived from the actual material [Früh 2011: 153]. Informed by previous research on media framing [see for example Chaban 2016; Knodt et al. 2017; Chaban et al. 2017; more specifically on EU relations to the Eastern neighbours see Kleinschnitger \& Knodt 2018], we measure the category Visibility through the indicators of "volume" (number of news items), the "length" of each article (short [ $<500$ words]; medium [500-1000 words]; large [ $>1000$ words]) and through the "degree of centrality" of the representation of EU-Ukraine relations as well as of the representation of the EU itself (minor [the EU and Ukraine are mentioned in passing, very briefly]; secondary [the EU and Ukraine are acting on par with other international actors]; major [the EU and Ukraine are the focus of the story]).

The Understanding category evaluates on the one hand the type of "interaction" of the actors presenting the relations between the EU and Ukraine within respective articles. We distinguish and code for different modes of interactions to evaluate the framing of the relations between the EU and Ukraine. The possible frames are "cooperation", "conflict", as well as "value-based", "interdependent", "no interaction" and "comparison". Cooperation is defined as interacting together with a win-win result. Conflict on the other hand refers to a situation where we observe conflicting interest with asymmetrical profit. Value-based interaction classifies a situation where at least one of the actors represents its normative ideas and values to influence its partners. Interactions were coded as interdependent if both interacting partners were presented as dependent on each other, with their actions having mutual, positive or negative outcomes for the other. Finally, no interaction is the code of cases when the actors do not interact in any way and comparison is the code for when the actors are compared in a rather neutral manner. We also considered that a pure description of facts is always influenced by the one presenting it. On the other hand, the Understanding category evaluates specific "thematic frames": "politics", "economy/business", "energy", "mobility" and "normative". These five identified thematic frames are reflective of the subject areas of the EaP. 
The thematic frames represent the thematic areas in which the actors of the EU-Ukraine relationship interact.

As part of the "image theory" tradition, Richard K. Herrmann [2013] emphasized emotive charge as one key condition for images of "Others" to leave a deeper imprint. Regarding the category Emotional Charge, we define the "evaluation" in the media items of the EU-Ukraine relations from "negative", "negative/neutral", "neutral", "positive/neutral", to "positive". Additionally, we analysed "metaphors" to evaluate the emotional charge in a nuanced way (about the theoretical foundations see the Conceptual Metaphor Approach by Lakoff \& Johnston [1980]). Metaphors are important sources to analyze how actors and their interaction are presented, as especially often these reveal an opinion and the choice e.g. of using "friendship" or "enemy" are crucial and are helpful in capturing perceptions. Metaphors can therefore prompt whether the actors are viewed as "negative", "neutral" or "positive". Metaphors play a crucial role in stereotyping and it is of great interest to see which, if any, stereotypical pictures can be worked out on the EUUkraine relation (Table 2).

Table 2

Categories of analysis

\begin{tabular}{|c|c|c|c|c|c|c|}
\hline \multicolumn{3}{|c|}{ Visibility } & \multicolumn{2}{|c|}{ Understanding } & \multicolumn{2}{|c|}{ Emotional Charge } \\
\hline $\begin{array}{c}\text { Volum } \\
\text { e }\end{array}$ & Length & $\begin{array}{c}\text { Degree } \\
\text { of } \\
\text { Centrality } \\
\text { (EU- } \\
\text { Ukraine } \\
\text { and EU) }\end{array}$ & Interaction & $\begin{array}{c}\text { Thematic } \\
\text { Frames }\end{array}$ & Evaluation & Metaphors \\
\hline $\begin{array}{l}\text { Numbe } \\
\text { r of } \\
\text { News } \\
\text { Items }\end{array}$ & $\begin{array}{l}\text { Short } \\
\text { Mediu } \\
\text { m } \\
\text { Large }\end{array}$ & $\begin{array}{l}\text { Minor } \\
\text { Secondary } \\
\text { Major }\end{array}$ & $\begin{array}{c}\text { Conflict } \\
\text { Cooperation } \\
\text { Interdepende } \\
\text { nce } \\
\text { Value-based } \\
\text { No } \\
\text { Interaction } \\
\text { Neutral } \\
\text { Comparison } \\
\text { Other }\end{array}$ & $\begin{array}{c}\text { Politics } \\
\text { Economy/ } \\
\text { Business } \\
\text { Energy } \\
\text { Mobility } \\
\text { Normative }\end{array}$ & $\begin{array}{c}\text { Positive } \\
\text { Positive/neutra } \\
1 \\
\text { Neutral } \\
\text { Negative/neutr } \\
\text { al } \\
\text { Negative }\end{array}$ & $\begin{array}{c}\text { Positive } \\
\text { Neutral } \\
\text { Negative }\end{array}$ \\
\hline
\end{tabular}

Source: compiled by the authors,

based on Chaban [2016: 104-109] and Knodt et al. [2017: 49].

3. Comparing media perceptions of EU-Ukraine relations in Germany and Russia

Focusing our research questions - how is the relationship between the EU and the Ukraine framed both in Germany's and Russia's print media and what different frames and images do they communicate? - this section presents the analysis of the empirical material on EU-Ukraine relations from the German and Russian samples. In it, we describe our empirical findings, include possible explanations of these and discuss the results within a broader context of the general discourses on the perceived EU relations with Ukraine. The section is structured to reflect the three main categories of analysis detailed above: Visibility, Understanding and Emotional Charge.

\subsection{Visibility of EU-Ukraine relations}

The formal institutionalization of the relations between Ukraine and the EU began with the signature of the Partnership and Cooperation Agreement (PCA) on June 14, 1994, which was ratified in March 1998. Subsequently, in February 2005, the EU and Ukraine adopted the EUUkraine Action Plan, which entailed political reforms and visa facilitation as a conditional basis for further trade relations. The tailor-made Action Plan represented a subsequent step in the 
formalization of EU-Ukraine relations and has been extended by implementation plans after three years' validity within the framework of the EaP.

Ukraine is a central state of the EaP and has been described by academics as the "driving force" [Trabandt 2012] for relations with the EU within the framework. This finding can be explained not only by its geographical size but also by the high status of economic relations with the EU and because of its significance in normative and geopolitical relations with Russia. Figure 1 shows the total volume of EU-Ukraine articles we have collected during the specific seven-year period around the biennial EaP summits. Remarkably, the Russian dataset on EU-Ukraine relations (49 articles) is less than half of the German dataset (111 articles). Looking at the data volume of EU-Ukraine over time, nearly half of the German as well as the Russian dataset cumulates in the year 2013 (Figure 1). This visibility pattern is rather predictable as the EU-Ukraine relationship becomes highly visible right at that moment, when the former president Viktor Yanukovych decided not to sign the AA to everybody's surprise.

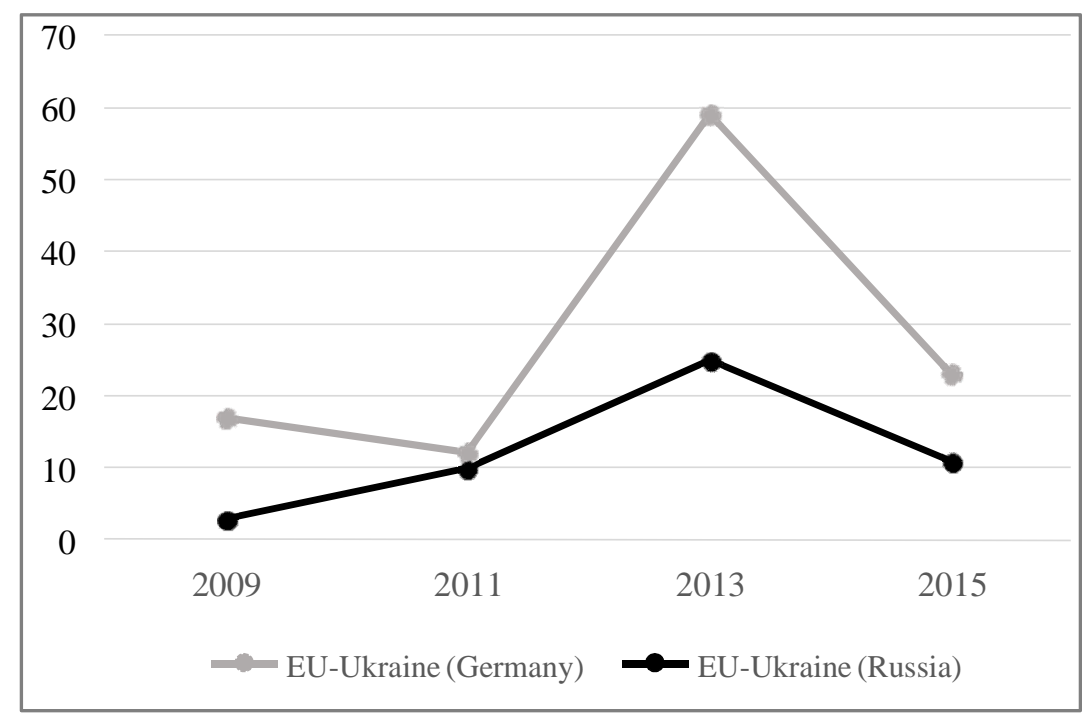

Figure 1: Volume on EU-Ukraine over time, 2009-2015

(German and Russian media).

Source: ENPerceptions, TU Darmstadt, 2016/2018

In contrast to the coverage of the crisis in 2013, the year 2011 represents the smallest volume of published articles in Germany. In the Russian case, it is the year 2009 with the lowest number of articles. Although 2009 is the founding year of the EaP and thus an important turning point for the development of EU-Ukraine relations, the Russian media gave little or no attention to this event.

Overall, the German dataset has 66 articles by the FAZ. These are followed closely by 45 articles by the $S Z$. In the Russian case, 37 articles came from $R G$, the dominant source for the data over time, and only 12 articles are from the daily newspaper Kommersant. Looking at the volume and the length of published articles (Figure 2), it is noticeable that, proportionally, Russian articles mentioning the EU and

Ukraine are large or at least medium in length. Short articles only appear in $25 \%$ (Kommersant) and 29\% $(R G)$ of media coverage. The German case, in comparison, included a rather high number of short articles - both German newspapers published about $60 \%$ short length articles. This empirical findings suggest, that in the German case the EU-Ukraine relationship was 'on the radar', which means that German media were following the developments in the EUUkraine relationship on a regular base, yet in a more superficial manner. In contrast, Russian media were much more case-sensitive. If they reported on EU-Ukraine relations, Russian media tend to discuss important changes in the EU-Ukraine relationship in a greater detail. 


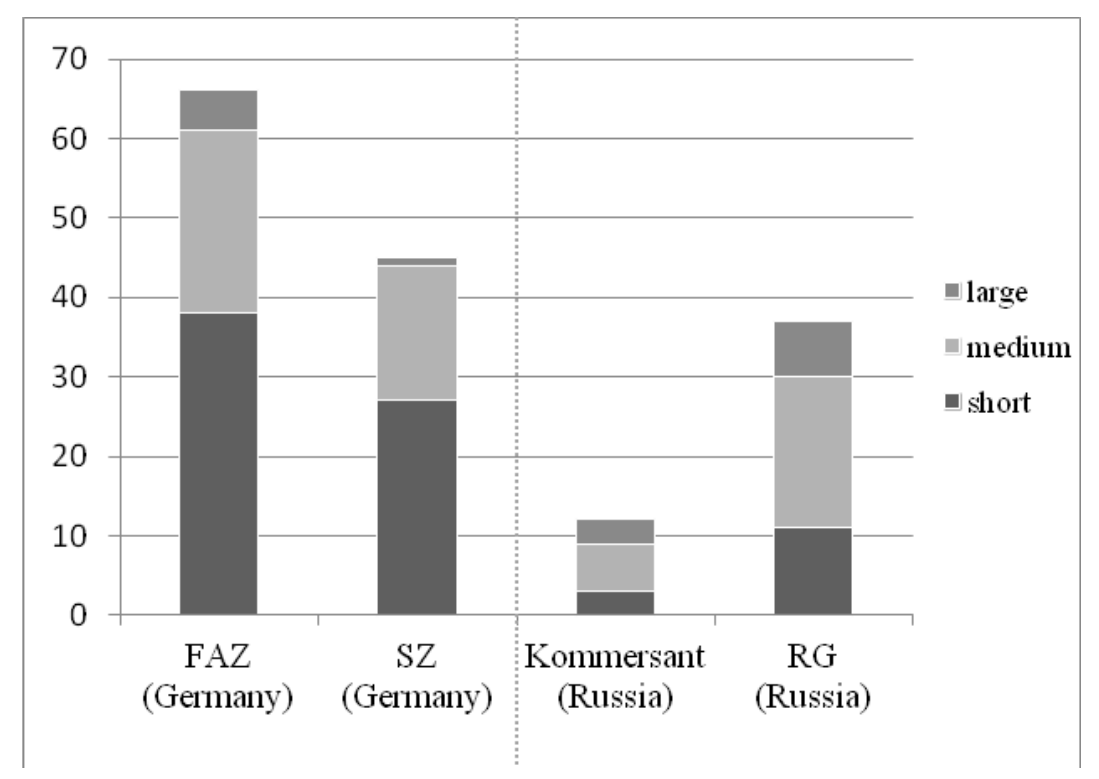

Figure 2: Volume and length on EU-Ukraine by newspaper, 2009-2015

(German and Russian media).

Source: ENPerceptions, TU Darmstadt, 2016/2018

Bringing the focus to the degree of centrality, the media analysis of the German and the Russian news reveals that the EU-Ukraine relations as well as the EU itself were presented mainly in a major or secondary perspective (Figure 3), which is a very strong finding. Arguably, it shows the importance assigned by newsmakers to the relationship between the EU and Ukraine. Both datasets contained a significant number of articles reporting about EU-Ukraine or the EU on its own either acting at least on par with other international actors (secondary) or even as the main focus of the story (major). The German media presents the EU-Ukraine in the main focus less frequently than the EU itself ( $40 \%$ vs. $62 \%$ of major focus respectively), which is not surprising due to the fact that for Germany as an EU member state the EU itself is more important in general. The situation is opposite in the Russian dataset. Here, the EU-Ukraine relationship is framed as the main focus of the story in $61 \%$ of the sample vis-à-vis $45 \%$ of articles where the EU on its own as a major focus. This indicator of visibility suggests that within Russian media the EU itself may be framed as less important than the EU's relationship with Ukraine. 


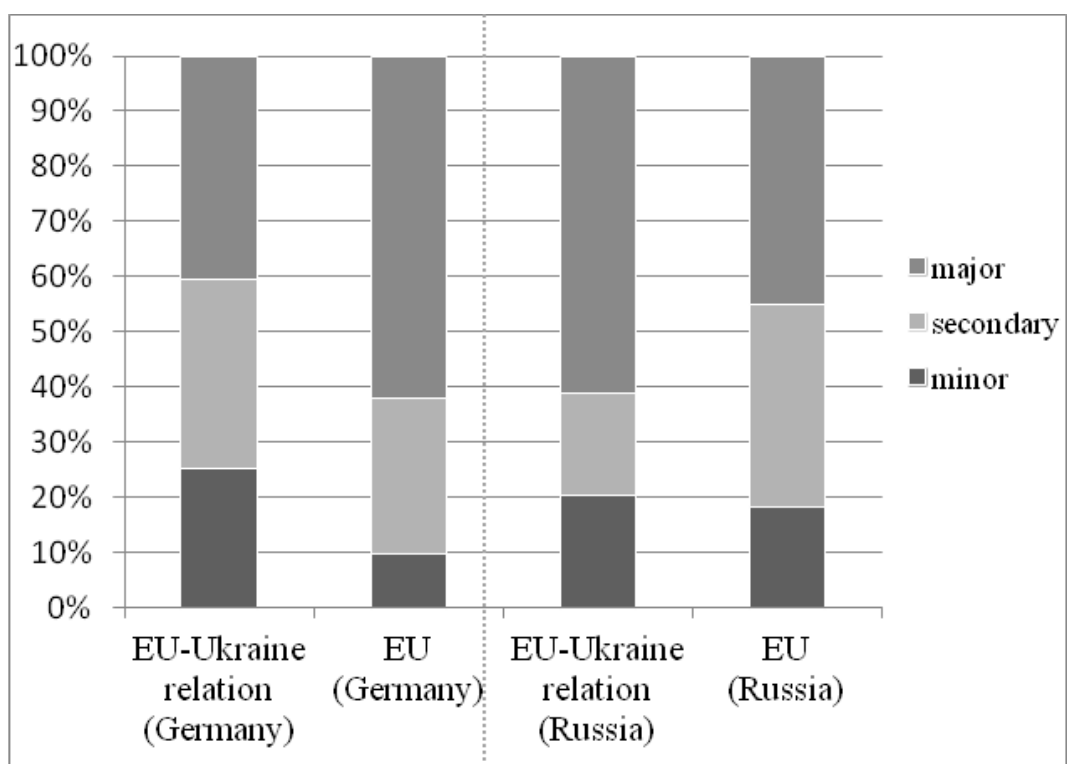

Figure 3: Degree of centrality of EU-Ukraine relations and of the EU, 2009-2015 (German and Russian media). Source: ENPerceptions, TU Darmstadt, 2016/2018

\subsection{Understanding EU-Ukraine relations}

From 2007 to 2011, the EU and Ukraine were negotiating an AA, which should have included an in-depth Deep and Comprehensive Free Trade Area (DCFTA) and aimed to further develop trade relations. When Viktor Yanukovych, however, won the presidential election in February 2010, two prominent events led to stagnating the development of the relations between the two parties in the following years. On the one hand, there were ongoing negotiations on association, complicated by the imprisonment of former opposition Presidential candidate Tymoshenko and, on the other hand, failure to reach agreements on the bilateral EU-Ukraine association in November 2013.

Looking at the patterns of interaction of the perceived relationship between the EU and Ukraine, at first glance, it appears that the German news sources portray EU-Ukraine relations under the "conflict" frame more than the Russian news sources (Figure 4). However, the section "others" under the Russia column in Figure 4, can almost exclusively be classified as "pressure" or "blackmail". Many of the Russian articles captured under "other" describe the EU as either pressuring Ukraine, or more extremely, blackmailing Ukraine. Also notable is that the majority of the articles that describe European pressure and blackmail are concentrated in 2013 when much of the news was focused on the AA. In conjunction with pressure from the EU, Russian articles also mention "empty promises" from the EU, which paints an even more negative image of the EU, and what the AA would bring to Ukraine. Furthermore, even the Russian articles that are classified under "neutral comparison", state that the AA with the EU would not be beneficial for Ukraine. 


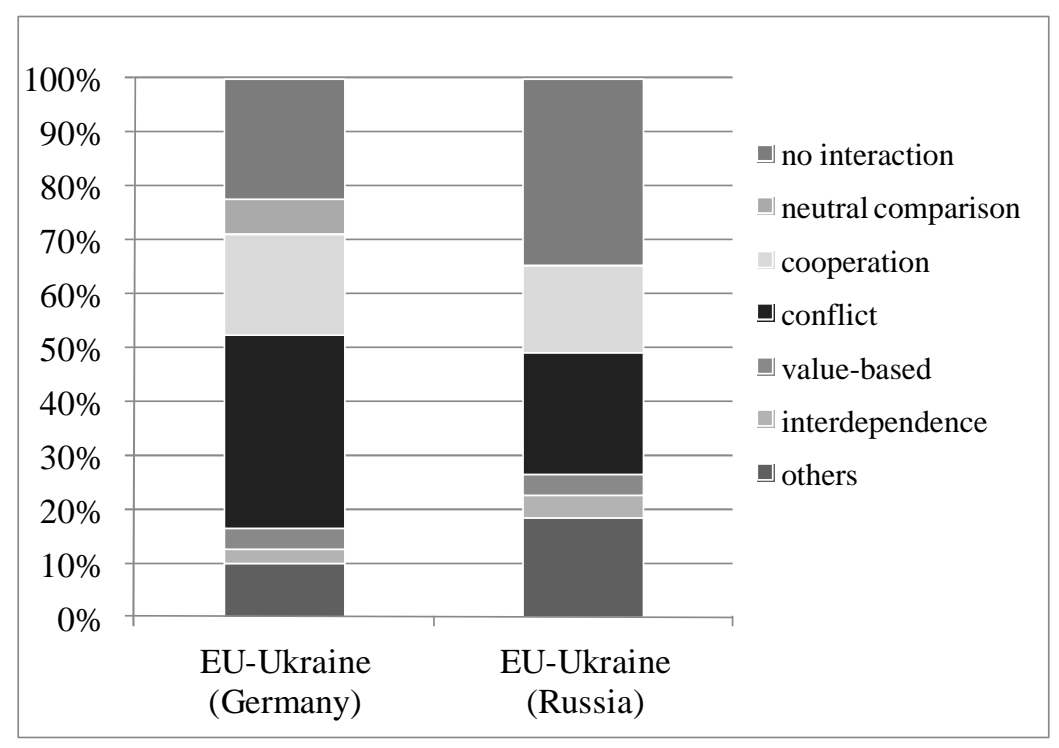

Figure 4: Patterns of interaction on EU-Ukraine relations, 2009-2015 (German and Russian media). Source: ENPerceptions, TU Darmstadt, 2016/2018

A significant majority of German and Russian articles on the EU-Ukraine relationship classified under "conflict", were clustered in 2013 mostly in respect to the refusal by Yanukovych to sign the AA (Figure 5), just before the Vilnius summit in 2013. As mentioned above, Russian media emphasised that the EU, as the dominant player, is blackmailing Ukraine. In contrast to the German articles, the Russian media clearly referred less to the conflict itself, but more to an apparent asymmetrical power relationship that prevails between the EU and Ukraine. This asymmetry puts the EU in a position to oppress Ukraine. The German articles, however, highlighted the non-signature of the AA and the connected conflict, and did not mention the asymmetrical power relationship.

Despite the troublesome domestic situation in Ukraine, on March 21, 2014 - during the threemonth transitional presidency of Oleksandr Turchynov - Ukraine signed the political part of the AA with the EU. Subsequently, on June 27, 2014, under the new, democratically elected President Petro Poroshenko, the economic part of the agreement was also signed. However, it was suspended until December 31, 2015, to find a settlement with Russia regarding compatibility with the DCFTA free trade agreement. The ratification by the Ukrainian Parliament of the Joint AA on September 16, 2014, marked the next, vital stage in cooperation and, as such, constituted the new foundation of EU-Ukraine relations. As Figure 5 shows, in the German sample, 2015 is the year with the highest share of reports framing the EU-Ukraine relationship in terms of "cooperation", which marked a change of the relationship towards more cooperative modes of interaction. In contrast, framing in terms of "cooperation" between the EU and Ukraine within the Russian sample stagnate since 2013. This stagnation is of interest - a higher level of cooperation is to be expected in 2015, as the AA signed in 2014 leads to deeper cooperation between the EU and Ukraine. It seems more likely that Russian media simply ignored the agreement and the subsequent deepening of EU-Ukraine relations. 


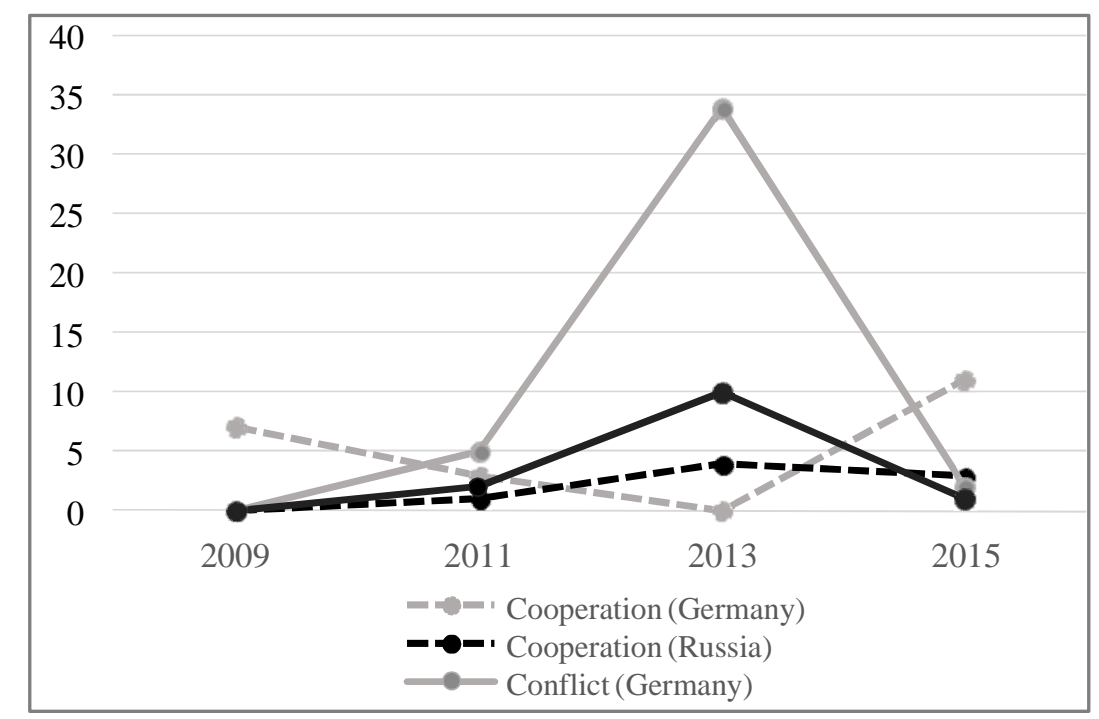

Figure 5: Patterns of Cooperation and Conflict on EU-Ukraine relations, 2009-2015 (German and Russian media). Source: ENPerceptions, TU Darmstadt, 2016/2018

Turning to the question of how EU-Ukraine relations were framed in the German and Russian media with respect to the thematic frames, such as politics, economy, energy, mobility and normative (Figure 6), the frames of "politics" and "economy" were found within more than $90 \%$ of the German media coverage over time. It seems that the influential German press delivers a strong message that the EU relationship with Ukraine focuses on economic and political issues. This framing can be explained - from a political point of view - by the fact that German media reports almost entirely about the ambitious reform agenda relating to the AA to deepening the EU-Ukraine relationship that includes huge reforms of the country's public administration and the judicial sector. In the reportage of EU-Ukraine relations in the Russian newspapers, the two frames, "politics" and "economy", accounted for just over 70\%. Strikingly, the frame of energy is barely visible in the German press, which might be an outcome of the German-Russian cooperation in the Northstream 2 project, which left Ukraine's role as a transit country unattended. In contrast, the energy frame in the Russian dataset on EU-Ukraine has almost the same percentage as the frame economy. This higher visibility reflects the status of Ukraine as a transit country for Russian gas, which has impacted energy supplies to the EU in the past. Since energy constitutes approximately half of Russian exports, energy prices are a critical factor to keeping Russia's economy stable. The majority of articles in the Russian sample that focused on energy, actually described no interaction between the EU and Ukraine, but focused more on Russia's interaction with Ukraine, in regards to price of energy and tariffs on gas. Finally, within the Russian sample, the normative frame is more prominent than in the German ones. In almost every "normative" framed article, the interaction between the EU and Ukraine was classified as neutral, and in one case negative/neutral. These articles were less about these interactions, and more about the EU's normative status in general. 


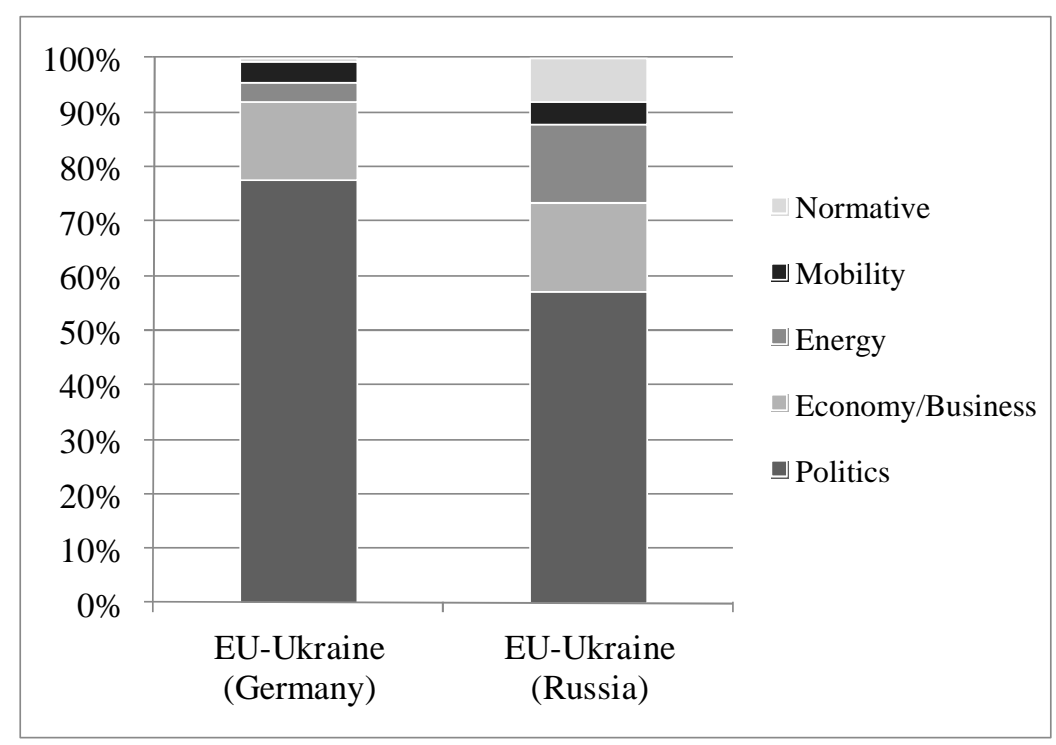

Figure 6: Dominant Thematic Frames on EU-Ukraine relations, 2009-2015 (German and Russian media). Source: ENPerceptions, TU Darmstadt, 2016/2018

The frame "mobility" shows in both datasets on EU-Ukraine interactions with the same low visibility despite that it is an important topic for Germany and Russia, in regards to visa liberalization for Ukrainian citizens to travel to and work in the Schengen area of the EU. However, the low visibility of this frame can be explained by the fact that our analysis ends in November 2015, but the agreement on visa liberalization between the EU and Ukraine came into force in June 2017. This agreement binds Ukraine even more closely to the EU.

\subsection{Emotional charge of EU-Ukraine relations}

Finally, the evaluation of EU-Ukraine relations shows that the distribution of classification of both German and Russian articles was skewed towards "negative" and "negative/neutral" (Figure 7). In the German case, there are some classifications of positive portrayals on EU-Ukraine relations (20\%). In contrast, there are absolutely no "positive" or "positive/neutral" evaluations of EUUkraine relations in the Russian sample. In addition to a higher percentage of "negative" classifications, the Russian articles also used more emotionally charged language, particularly through the use of metaphors. The articles that are classified as "neutral" in the Russian case mostly refer to the EU, or Ukraine, in relation to the EU in a minor way. Other "neutral" articles, which were written in a more diplomatic way, acknowledged that many Ukrainians want eurointegration, but still highlighted that Ukraine and Russia are very closely tied through history, culture and mentality. These articles do not openly oppose Ukraine's closer ties with the EU, but at the same time emphasis that the AA should not harm the Ukrainian economy or Ukraine's close ties with Russia. Other neutrally written Russian articles stated only facts about the EU, and did not impose any views through the tone or metaphors used. However, even the neutrally stated facts about the EU often implies a great deal of negativity towards the EU. 


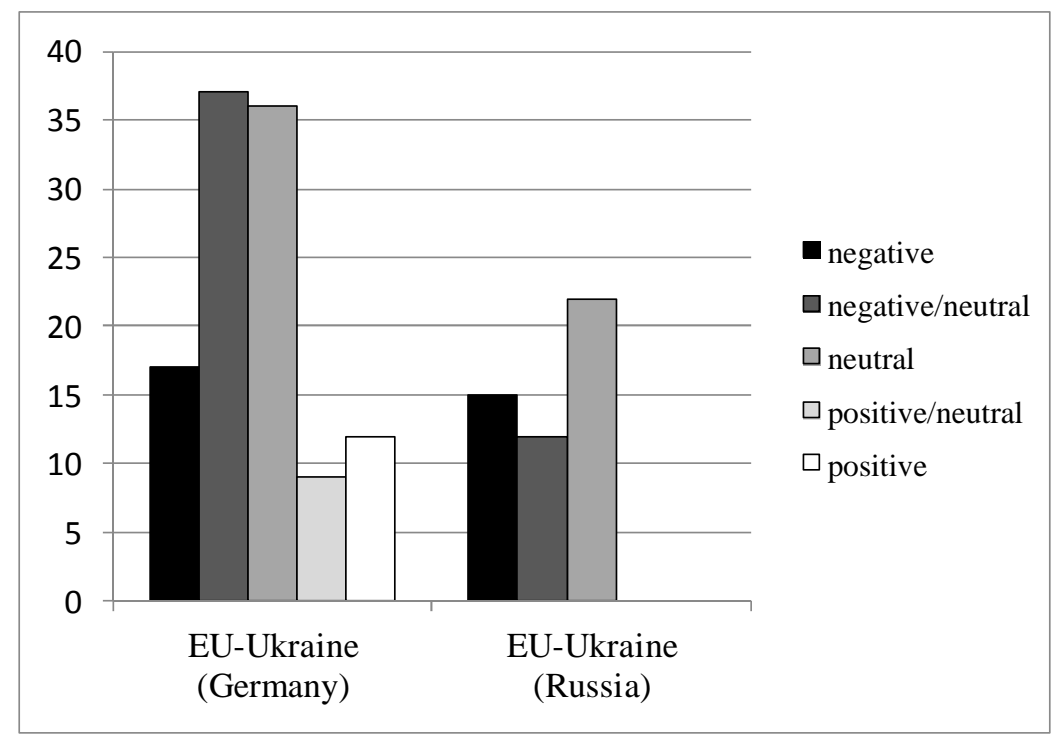

Figure 7: Evaluation of EU-Ukraine relations in comparison, 2009-2015 (German and Russian media)

Source: ENPerceptions, TU Darmstadt, 2016/2018

As mentioned earlier, metaphors play a crucial role in framing the international actors, often engaging with stereotypes. In this analysis, we discuss only the most typical metaphors which described the EU, Ukraine, or the relations between them. Such metaphors are the ones of sickness, negative emotions, war, flood, game etc.

Metaphors were rarely used in the German sample. $S Z$ was more prone to use metaphorical images than the FAZ. Most metaphors were found in the crisis year of 2013 in the articles referring to Yanukovych's decision not to sign the AA. The sudden rejection of the AA by Yanukovych was negatively described by the German media. It was compared to "A Ukrainian bomb for the EU" [FAZ 2013a], one of the strongest negative metaphor we found in our data. In addition to this war metaphor, the game metaphor was often used in this case: German media described Yanukovych as a "juggler" [SZ 2013a; SZ 2013b]. In another instance, a negative image emerges again: "just look at his cards and compare them with the cards in Putin's hands" [SZ 2013c]. The image that comes through is the one of the Ukrainian leadership at the time who did not take the association seriously and played with the EU. A rather neutral game metaphor could be the verbal image "end of swinging" [SZ 2013d], which refers to the fact that the decision has now been made and there is probably no AA between the EU and Ukraine. A similar intention has the rather neutral theater metaphor "curtain after the interval" [SZ 2013e], which suggests that the decision has been made too early. Positive metaphors were also found in German data - e.g. "friendship" [SZ 2015] or the "European family" [e.g. FAZ 2013b; SZ 2013f]. The family metaphor is a very strong positive emotionally charged verbal image and highlights the closeness and togetherness that prevails despite many quarrels between the EU and Ukraine, not only geographically but also emotionally.

In contrast to the German media, both observed Russian newspapers used metaphors frequently. All metaphors are charged on the spectrum from neutral to very negative, while not a single metaphor with positive connotations was observed. One of the reoccurring negative metaphors used to describe EU-Ukraine relationship was the one of the "carrot" [Kommersant 2013a] or the "sweet gingerbread" [ $R G$ 2013a]. The sweet gingerbread, which is offered by the EU, symbolized the EU promise of integration to attract Ukraine's youth - perhaps, a parallel to the fairytale about Hansel and Gretel, a storyline which did not end well for the children (Ukraine in 
this case), on the one hand. On the other hand, when it came to Yanukovich's decree finally the "carrot" will not be given to the Ukrainians. Some metaphors within the Russian dataset took this idea and made it even more negative by stating that the carrot had no real substance and that you cannot "spread a promise onto bread" [e.g. $R G$ 2013b]. It meant that the promises the EU was giving about integration were empty, they would not bring real economic benefit to Ukraine. However, when it comes to discussing blackmailing, some articles used that terminology in a harsh and bold way [ $R G$ 2013c; $R G$ 2013d; Kommersant 2013b]. Directly following the Vilnius Summit, a Russian article praised Kiev for not "succumbing to euroblackmail" [RG 2013e].

Referring to EU integration in a more negative manner, the news authors came with such expression as "the only free cheese comes in a mousetrap" $[R G$ 2013f] stressing that Ukraine will have to pay a high price for joining the EU. Another metaphor which also relates to life threatening devices is the description by the Russian media of the AA as "a noose around Ukraine's neck" $[R G$ 2013g].

Metaphors of fluidity are used in different ways. For example, when some articles describe the Ukraine "comes out dry from water" [e.g. Kommersant 2013c], it implies that signing the AA means a great deal of troubles to Ukraine. But they also admonish that it is too early "to drink champagne" about stopping the movement of Ukraine to Europe and "the drink is European, and with gas" $[R G 2013 \mathrm{e}]$. Metaphors relating to hot temperature are often used referring to the Maidan movements: while "Maidan is boiling" [e.g. $R G$ 2013h], the economists discuss how the AA will turn out for Ukraine's economy. In this regard, it is important to "save Ukraine from the imperial nightmare" [e.g. $R G$ 2013i] the EU is trying to impose, some article stated.

The game metaphor is often used when energy policy is reported. Journalists are trying to understand which "games each side is playing" [ $R G$ 2009] or regarding Ukraine, which is like an "active item" $[R G 2013 \mathrm{i}]$ on an overheated market where the players inflate the prices hoping to make some profit. In a more sarcastic manner, some say that the EU does not act out of some moral ideological ideas, but out of self-interest. Therefore, the EU only intervenes if there is some strategic benefit to them: "Oil was found in the Antarctic. Luckily the bloody regime of the penguins does not have much time left to torture its people" [RG 2011].

When reporting the EaP, Russian articles described the hopelessness of the EU the most: e.g. "fishing without catching a fish" $[R G 2015]$ referred to the EU as a fisherman who is trying to get a moldy worm onto a rusty and dull hook with the hope that a fish will bite. Regarding the EU itself, Russian articles use the sickness metaphor, for example, saying that the EU has an "allergy" [Kommersant 2013a] towards Russia and everything what this country stands for. The family metaphor is used not only in the German media but also in Russian articles when it says that Ukrainians are not "small children" $[R G$ 2013j] who are scanty for sweet candies. While the German media frames the EU and Ukraine as a "European family", the Russian media emphasize that Ukrainians are not children and not even "poor relatives" [RG 2013j].

\section{Conclusions}

In the conclusions we are coming back to our initial research questions - How is the relationship between the EU and the Ukraine framed both in Germany's and Russia's print media? And what different frames and images do they communicate? Using methods from multidisciplinary backgrounds, we conducted a mixed (qualitative and quantitative) content analysis and analyzed leading newspapers in Germany (EU-internal perspective) (Frankfurter Allgemeine Zeitung and Süddeutsche Zeitung) and in Russia (EU-external perspective) (Kommersant and Rossiskaya Gazeta). We aimed to grasp the leading frames of EU-Ukraine relations from both perspectives. The period of observation stretches from 2009 (the launch of the EaP) to the important EaP summit in Riga in 2015 (which followed the unfolding of the Russia-Ukraine crisis).

The comparison between the framing of EU-Ukraine relationship in the German vs. Russian leading newspapers showed that the Visibility of these relations differs widely between Germany 
and Russia. Overall, the German dataset (111 news items total) count for a significantly larger volume of articles than the Russian dataset (49 news items in total) on EU-Ukraine relations within the similar time period. However, even though the number of Russian articles is significantly lower, Russian media tend to report EU-Ukraine relations in a greater detail, as explicated by a larger proportion of medium and large articles in the Russian dataset. In contrast, more articles with short lengths in German sample demonstrated that the relationship between the EU and Ukraine is 'on the radar' of the German newsmakers. A high proportion of articles that framed EU-Ukraine relations with a higher degree of centrality was found in both datasets. In other words, if the EU and Ukraine are both mentioned in an article, their relationship is mainly the focus of the story within the German as well as the Russian media. Visibility patterns suggest that while Germany and Russia focus on EU-Ukraine relations, they do it differently: Russian leading press prefers to cover them in lesser but more detailed articles, while German newsmakers publish more and more regularly, yet in shorter, less elaborated articles.

Concerning the Understanding of EU-Ukraine relations, the second main category of our analysis, thematically, the dominant frames of 'politics' and 'economy' were found within more than $90 \%$ of the German sample. In the Russian case, these frames accounted for about $70 \%$. Importantly, the frame of energy in the Russian dataset on EU-Ukraine relations has almost the same percentage as the frame economy which reflects the framing of Ukraine as a transit country for Russian gas. In terms of the perceived interaction modes, a significant majority of German and Russian articles on EU-Ukraine relations classified these relations under "conflict". These were clustered mostly in 2013. German media mostly focusses on the decree of the former Ukrainian president Viktor Yanukovych who refused to sign the AA with the EU. In contrast, Russia's media emphasizes that the EU, as the dominant player, was blackmailing Ukraine and referred less to the conflict itself, but more to an apparent asymmetrical power relationship that prevails between the EU and Ukraine. The year 2015 is the year with the highest share of reports framing the EUUkraine relationship in terms of "cooperation" in the German case. This framing marked a change in the framing of the relationship towards more cooperative modes of interaction. In contrast, the perceived "cooperation" rate between the EU and Ukraine within the Russian media articles has been stagnant since 2013 .

The evaluation of the third main category Emotional Charge shows that evaluations of EUUkraine relations in both German and Russian samples was skewed towards "negative" and "negative/neutral". In the German case, there were some positive portrayals on EU-Ukraine relations ( $20 \%$ of the German articles). Importantly, there were absolutely no "positive" or "positive/neutral" evaluations of EU-Ukraine relations in the Russian sample. In addition, when assessing the metaphors, Russian newsmakers were found to use them more frequently. None of these metaphors has positive connotations when describing the relationship between the EU and Ukraine.

Interestingly, shifts in the real world of European foreign policy mirror Russia's critics of the EU or could be read as an answer to this critique. As mentioned in the beginning of the article, the EU Global Strategy and the related new developments towards a new pragmatism mark a shift from an asymmetrical relationship to joint ownership. This new pragmatism of the EU gives the impression of a kind of 'response' to the framing of the EU-Ukraine relations produced by the Russian press. No other country has criticized EU policies as much as Russia has done, especially towards its Eastern European neighbours within the EaP. Somehow, it looks like the framing by Russian leading media might have contributed to the development of the strategic direction of EU's foreign policy and the shift towards a new pragmatism but also towards joint ownership. More research is needed to analyse this potential "feedback loop" of the media frames of third countries towards the EU's foreign policy. Nevertheless, if the administration level in Entman's cascade is influenced not only by the country-specific media interpretations and supply of new frames but also by the media interpretations and supply of frames by third countries, then the feedback loop of the 
cascade may provide a 'loose coupling' to third countries cascades. Arguably, frames of foreign policy may not only travel 'down' the cascade from the government to the public and in the reverse flow, but also from one country cascade to another country cascade.

\section{NOTES}

1. A pan-Europe weekly Politico has a very low volume of publications on the EU-Ukraine relations, thus it has been excluded from the analysis.

2. $\quad S Z$ is mainly owned by the "Südwestdeutsche Medien Holding GmbH", a company based in Stuttgart in Germany. FAZ belongs to the majority of the non-profit "Fazit-Stiftung", a foundation based in Frankfurt am Main in Germany. The current circulation of $S Z$ is 366.999 newspapers/day (IVW/II.2018). While $F A Z$ has a lower number of circulation with 261.583 newspapers/day (IVW/II. 2018), for more information about circulation numbers see: www.ivw.eu.

\section{REFERENCES}

Bersick, S., Bruter, M., Chaban, N., Inglesias, S., \& Lenihan, R. (2012). Asia in the Eyes of Europe: The EU's Perception of Rising Asia, in: Asia in the Eyes of Europe. Images of a Rising Giant, 7-23. Baden-Baden: Nomos Verlag.

Blumler, J., \& Katz, J. (1974). The Uses of Mass Communications. Beverly Hills, CA: Sage.

Casier, T. (2017). EU-Russia Relations in Crisis: The Dynamics of a Breakup, in: EU-Russia Relations in Crisis. Understanding Diverging Perceptions, 13-29. New York, NY: Routledge.

Chaban, N. (2016). How to Work with Media Content, in: ASEF Public Diplomacy Handbook: How to Win Hearts and Minds, 88-110. Singapore: Asia-Europe Foundation.

Chaban, N., Bain, J., \& Kelly, S. (2014). En'vision'ing Europe's crisis: Intertextuality in news coverage of the Eurozone crisis in Chinese, Indian and Russian press. Journal of Communication, 20 (1), 1-20.

Chaban, N., Bain, J., Stats, K., \& Sutthisripok, P. (2008). Mirror reflections? The EU in print and broadcast media in Asia-Pacific, in: The European Union and the Asia-Pacific: Media, Public and Elite Perceptions of the EU, 22-61. New York, NY: Routledge.

Chaban, N., \& Holland, M. (2008). Introduction. Research rationale, theoretical underpinnings and methodological considerations, in: The European Union and the Asia Pacific: Media, Public and Elite Perceptions of the EU, 1-21. New York, NY: Routledge.

Chaban, N., \& Holland, M. (2014). Communicating Europe in Times of Crisis: External Perceptions of the European Union. New York, NY: Palgrave McMillan.

Chaban, N., \& Holland, M. (2015). EU External Perceptions: From Innovation to an Established Field of Study, in: The SAGE Handbook of European Foreign Policy, 672-686. London: Sage.

Chaban, N., Knodt, M., \& Verdun, A. (2017). 'Talking with' Not 'Talking at'? Perceptions of the EU as a Global Normative Energy Actor in the Eyes of BRICS and EU 'Big 3'. Comparative European Politics, 15 (1), 1-22.

Cohen, B.C. (1967). The Press and Foreign Policy. Princeton: Princeton University Press.

EEAS (European External Action Service). (2015). ENP Review: stronger partnerships for a stronger neighbourhood, 17.11.2015.

http://collections.internetmemory.org/haeu/content/20160313172652/http://eeas.europa.eu/top _stories/2015/181115_enp_review_en.htm. Accessed 10 June 2018.

Elgström, O., \& Chaban, N. (2015). To Study External Perceptions of the EU: A Conceptual Approach, in: Perceptions of the EU in Eastern Europe and Sub-Saharan Africa Looking in from the Outside, 17-33. New York, NY: Palgrave McMillan.

Entman, R.M. (2003). Cascading Activation: Contesting the White House's Frame After 9/11. Political Communication, 20 (4), 415-432. 
Entman, R.M. (2004). Projections of Power: Framing News, Public Opinion, and U.S. Foreign Policy. Chicago: University of Chicago Press.

European Commission. (2015). Joint Communication to the European Parliament, the Council, the European Economic and Social Committee and the Committee of the Regions, Review of the European Neighbourhood Policy, JOIN(2015) 50 final, 2, 18 Nov. 2015, Brussels.

Früh, W. (2011). Inhaltsanalyse. München: UVK.

Häder, M. (2006). Empirische Sozialforschung. Eine Einführung. Wiesbaden: VS Verlag.

Herrmann, R.K. (2013). Perceptions and Image Theory in International Relations, in: The Oxford Handbook of Political Psychology, 285-314. Oxford: Oxford University Press.

Kleinschnitger, K., \& Knodt, M. (2018). Asymmetric Perceptions of EU Relations with the near Eastern Neighbours: The Republic of Moldova, Ukraine and Belarus in Comparison. European Foreign Affairs Review, 23 (1), 79-100.

Knodt, M., Chaban, N., \& Nielsen, L. (2017). Bilateral Energy Relations Between the EU and Emerging Powers: Mutual Perceptions of the EU and Brazil, China, India and South Africa. Baden-Baden: Nomos Verlag.

Lakoff, G., \& Johnston, M. (1980). Metaphors We Live By. Chicago: University of Chicago Press. Livingston, S. (1997). Clarifying the CNN Effect: An Examination of Media Effects According to Type of Military Intervention, Research Paper, John F. Kennedy School of Government's Joan Shorenstein Center on the Press, Politics and Public Policy at Harvard University. Cambridge: Harvard University.

McCombs, M., \& Shaw, D. (1972). The Agenda-Setting Function of Mass Media. Public Opinion Quarterly 36, 176-187.

Semetko, H.A., De Vreese, C.H., \& Peter, J. (2000). Europeanised Politics - Europeanised Media? European Integration and Political Communication, 23 (4), 121-141.

Trabandt, V. (2012). Neue Nachbarn, gute Nachbarschaft? Die EU als internationaler Akteur am Beispiel ihrer Demokratieförderung in Belarus und der Ukraine 2004-2009. Stuttgart: Ibidem-Verlag.

Vowe, G. (2002). Politische Kommunikation. Ein historischer und systematischer Überblick der Forschung. Ilmenau: Technische Universität Ilmenau.

Westle, B. (2009). Methoden der Politikwissenschaft. Baden-Baden: Nomos Verlag.

\section{DATA SOURCES}

FAZ (Frankfurter Allgemeine Zeitung). (2013a). Eine ukrainische Bombe für die EU, 23.11.2013.

FAZ (Frankfurter Allgemeine Zeitung). (2013b). Weiter Proteste in der Ukraine, 27.11.2013.

SZ (Süddeutsche Zeitung). (2013a). Viel Moral, wenig Muskeln, 30.11.2013.

SZ (Süddeutsche Zeitung). (2013b). Ukraine stellt den Westen auf die Probe - Präsident Janukowitsch ist derzeit nicht bereit, dass Assoziierungsabkommen mit der EU zu unterzeichnen, 22.11.2013.

SZ (Süddeutsche Zeitung). (2013c). Der Trickser - Der Präsident der Ukraine brüskiert die EU und freut sich über die Proteste. Beides dient seinem Machterhalt, 30.11.2013.

SZ (Süddeutsche Zeitung). (2013d). Ende des Schaukelns, 22.11.2013.

SZ (Süddeutsche Zeitung). (2013e). Vorhang nach dem Zwischenakt, 22.11.2013.

SZ (Süddeutsche Zeitung). (2013f). Zug nach Westen, 23.11.2013.

SZ (Süddeutsche Zeitung). (2015). Doch irgendwie Freunde - Griechenland, Ukraine, abtrünnige

Briten: Trotz Krisen endet der Osteuropa-Gipfel in Riga versöhnlich, 24.05.2015.

Kommersant. (2013a). Цена вопроса, 02.12.2013.

Kommersant. (2013b). Казань вступила в противоречия с Вильнюсом, 30.11.2013.

Kommersant. (2013c). Виктор Янукович вышел сухим из беды, 30.11.2013.

$R G$ (Rossiskaya Gazeta). (2009). Газовый ключ, 30.04.2009.

$R G$ (Rossiskaya Gazeta). (2011). Подчинись или стань злодеем, 30.09.2011. 
$R G$ (Rossiskaya Gazeta). (2013a). Кулаки по-киевски, 29.11.2013.

$R G$ (Rossiskaya Gazeta). (2013b). Обещания на хлеб не намажешь, 25.11.2013.

$R G$ (Rossiskaya Gazeta). (2013c). Время не ждет, 25.11.2013.

$R G$ (Rossiskaya Gazeta). (2013d). Еврокомиссары наносят "Удар", 02.12.2013.

$R G$ (Rossiskaya Gazeta). (2013e). Киев не поддался еврошантажу, 25.11.2013.

$R G$ (Rossiskaya Gazeta). (2013f). Майданофобия, 27.11.2013.

$R G$ (Rossiskaya Gazeta). (2013g). Майдан разгонять не будут, 27.11.2013.

$R G$ (Rossiskaya Gazeta). (2013h). Через Майдан, 27.11.2013.

$R G$ (Rossiskaya Gazeta). (2013i). Украина на ярмарке амбиций, 27.11.2013.

$R G$ (Rossiskaya Gazeta). (2013j). В Вильнюс без подписи, 29.11.2013.

$R G$ (Rossiskaya Gazeta). (2015). Саммит без наживки, 21.05.2015.

Katharina Kleinschnitger - PhD Candidate and Research fellow at Technical University of Darmstadt, Institute of Political Science (Dolivostraße 15, 64293 Darmstadt, Germany), e-mail: kleinschnitger@pg.tu-darmstadt.de

Катарина Кляйншнітгер - PhD-кандидат і дослідник, Технічний університет Дармштадту, Інститут політичних наук (Dolivostraße 15, 64293 Darmstadt, Germany), e-mail: kleinschnitger@pg.tu-darmstadt.de

Катарина Кляйншнитгер - $\mathrm{PhD}$-кандидат и исследователь, Технический университет Дармштадта, Институт политических наук (Dolivostraße 15, 64293 Darmstadt, Germany), e-mail: kleinschnitger@pg.tu-darmstadt.de

Michèle Knodt - Professor at Technical University of Darmstadt, Institute of Political Science (Dolivostraße 15, 64293 Darmstadt, Germany), e-mail: knodt@pg.tu-darmstadt.de

Мімель Кнодт - професор, Технічний університет Дармштадту, Інститут політичних наук (Dolivostraße 15, 64293 Darmstadt, Germany), e-mail: knodt@pg.tu-darmstadt.de

Мімель Кнодm - профессор, Технический университет Дармштадта, Институт политических наук (Dolivostraße 15, 64293 Darmstadt, Germany), e-mail: knodt@pg.tu-darmstadt.de

Nadiya Safonova - MA, Candidate at Carleton University, Ottawa (1125 Colonel By Dr, Ottawa, ON K1S 5B6, Canada), email: nadiya.safonova@ carleton.ca

Надя Сафонова - магістр-кандидат, Карлтонський університет, Оттава (1125 Colonel By Dr, Ottawa, ON K1S 5B6, Canada), email: nadiya.safonova@carleton.ca

Надя Сафонова - магистр-кандидат, Карлтонский университет, Оттава (1125 Colonel By Dr, Ottawa, ON K1S 5B6, Canada), email: nadiya.safonova@carleton.ca 